\title{
A Caminhada da Sociedade Brasileira de Atividade Física e Saúde: percursos, tropeços e próximos passos
}

Rodrigo S. Reis ${ }^{1,2}$

Mathias R. Loch ${ }^{3}$

Cassiano R. Rech ${ }^{4}$

Adriano A.F. Hino ${ }^{1,2}$

Priscila B. Gonçalves 1,2

Rev Bras Ativ Fis Saúde p. 2-2

DOI

http://dx.doi.org/10.12820/rbafs.v.19n1p2

1 Pontifícia Universidade Católica do Paraná

2 Universidade Federal do Paraná

3 Universidade Estadual de Londrina

4 Universidade Federal de Santa Catarina

Em breve daremos oficialmente inicio às atividades da gestão 2014-2015 da Sociedade Brasileira de Atividade Física e Saúde (SBAFS). Ao nos lançarmos para esta jornada tínhamos a certeza de que houve avanços que, em uma analogia simples, "abriram estrada" desde a criação da SBFAS até este momento. Por isto, somos gratos aos professores Markus Vinicius Nahas, Dartagnan Pinto Guedes e Pedro Curi Hallal que pavimentaram o caminho e deram o Norte inicial para que a SBAFS chegasse até este ponto da estrada.

O percurso trilhado pela SBAFS é sem dúvida exitoso, demonstrado, por exemplo, pela consolidação do Congresso Brasileiro de Atividade Física e Saúde, da Revista Brasileira de Atividade Física e Saúde ou ainda pelo inicio dos cursos de capacitação de pesquisadores, porém não foi livre de tropeços e subidas íngremes. Desde o inicio a SBAFS tem tido dificuldade em alavancar o número de sócios. Ainda que a área como um todo tenha crescido em quantidade e qualidade de publicações, e de grupos e linhas de pesquisa, este crescimento não se refletiu em aumento de associados. Além disto, ainda há dificuldade em levar a SBFAS para todas regiões do país.

Portanto, o caminho a ser percorrido é claro, há que se aumentar o número de sócios e também a representatividade da SBAFS junto a profissionais, estudantes e pesquisadores. Ao longo dos dois anos que estaremos à frente da SBAFS, pretendemos criar as condições para que a estrada possa chegar às mais diferentes regiões do país e que alcance um maior número de pessoas. Para isto, pretendemos fortalecer os eventos regionais, dar mais visibilidade e acesso a todas ações da diretoria e iniciativas dos associados da SBAFS e também consolidar os cursos de preparação de pesquisadores e profissionais.

Para tanto, precisamos certamente do trabalho de muitos, afinal com a vastidão do país e a diversidade de ações, interesses e necessidades que a nossa área possui, apenas o esforço de todos nós, enquanto área de interesse, produzirá os resultados esperados. Convidamos a todos para contribuírem com ideias, projetos, críticas e principalmente motivação para que possamos juntos conduzir a SBFAS nesta jornada ao longo dos próximos dois anos. Vamos juntos arregaçar as mangas e construir uma sociedade que seja representativa e contribua para que mais pessoas tenham acesso e oportunidades para uma vida mais fisicamente ativa. Vamos ao trabalho, ou como diria o poeta Paulo Leminski "Sentado não tem sentido". 